\title{
Meta
}

Journal des traducteurs

Translators' Journal

\section{Strategic Collaboration as a Means of Mediation in Translating Culturally Ambiguous Text: A Case Study}

\section{Dae-jin Kim}

Volume 51, numéro 2, juin 2006

Théories et pratiques de la traduction et de l'interprétation en Corée Theories and Practices of Translation and Interpretation in Korea

URI : https://id.erudit.org/iderudit/013258ar

DOI : https://doi.org/10.7202/013258ar

Aller au sommaire du numéro

Éditeur(s)

Les Presses de l'Université de Montréal

ISSN

0026-0452 (imprimé)

1492-1421 (numérique)

Découvrir la revue

Citer cet article

Kim, D.-j. (2006). Strategic Collaboration as a Means of Mediation in Translating Culturally Ambiguous Text: A Case Study. Meta, 51(2), 304-316.

https://doi.org/10.7202/013258ar
Résumé de l'article

Notre étude tente de réfléchir sur la collaboration stratégique entre les traducteurs de nationalités différentes lors de la traduction de « textes culturellement ambigus ». Pour ce faire, nous avons analysé les opinions et les commentaires échangés sur le web entre le traducteur coréen et le traducteur américain pour traduire ensemble un texte coréen en anglais. Une taxonomie spécialement établie pour mesurer l'effort de collaboration est utilisée pour analyser chaque échange d'opinions. Le résultat de notre étude montre que les textes culturellement ambigus peuvent être traduits avec beaucoup plus d'efficacité quand coopèrent un traducteur connaissant la culture du texte de départ et un natif de la langue d'arrivée. Des exemples concrets sont présentés pour montrer le processus de médiation et de négociation durant la traduction. 


\title{
Strategic Collaboration as a Means of Mediation in Translating Culturally Ambiguous Text: A Case Study
}

\author{
DAEJIN KIM \\ Seoul National University of Technology, Seoul, Korea \\ daejkim@chol.com
}

\section{RÉSUMÉ}

Notre étude tente de réfléchir sur la collaboration stratégique entre les traducteurs de nationalités différentes lors de la traduction de «textes culturellement ambigus». Pour ce faire, nous avons analysé les opinions et les commentaires échangés sur le web entre le traducteur coréen et le traducteur américain pour traduire ensemble un texte coréen en anglais. Une taxonomie spécialement établie pour mesurer l'effort de collaboration est utilisée pour analyser chaque échange d'opinions. Le résultat de notre étude montre que les textes culturellement ambigus peuvent être traduits avec beaucoup plus d'efficacité quand coopèrent un traducteur connaissant la culture du texte de départ et un natif de la langue d'arrivée. Des exemples concrets sont présentés pour montrer le processus de médiation et de négociation durant la traduction.

\section{ABSTRACT}

This paper attempts to explore the notion of mediation processes involved in strategic collaboration in translating culturally ambiguous texts. Data for analysis were gathered from on-line exchanges of opinions and comments accrued through the reciprocal translation processes between Korean and American translators. Analytic taxonomy to determine collaboration efforts was established and every exchange of transactions was analyzed in accordance with the taxonomy. The result of this study suggests that the translation of culturally ambiguous texts can be facilitated through highly mediated collaboration between two participants, one of whom is well versed in cultures of the source text (Korean) whereas the other partner is native speaker of the target text (English). Actual samples of transactions are presented with analysis on mediation and negotiation processes.

\section{초록}

이 논문은 문화적 차이와 해석의 임의성으로 인해 까다롭고 오해의 여지가 있는 텍 스트의 번역을 위해 원문에 나타난 문화적 특징을 잘 이해하고 있는 번역자와 번 역 목표어가 모국어인 두 번역자가 전략적 협조를 통한 조정 (mediation) 과정을 거 쳐 번역이 완성되는 과정에 대한 사례연구이다. 양 번역사간의 협상과 조정 과정을 분석하기 위한 분석틀을 수립하였으며 이 분석 틀에 의거 두 번역사간의 번역물과 의견교환 이메일을 분석하였다. 분석 결과 두 번역사 사이에는 문화적 어려움을 극 복하기 위한 전략적 협조와 조정이 전개되었음을 알 수 있었으며 이러한 협조의 전 개 형태는 사회문화적 인지 처리 과정을 연구한 비고스키의 심리언어 모델에 의해 설명하였으며 두 번역사 간에 교환된 실제 교신의 예도 제시되었다.

\section{MOTS-CLÉS/KEYWORDS}

languages and cultures, translatability, strategy, vygotskian mediation, cultural ambiguity 


\section{Introduction}

According to earlier observation (Nida and Taber, 1969) on translation endeavors, any intentions articulated in one language can be conveyed in another language, unless the form is the prime importance of the message. On the other hand, some scholars (e.g. Wilss, 1982) argued that translation from one language to another is impossible due to the structural incompatibility between two languages. To support this, Gentzler (1993) asserted that, in spite of the structural similarities underlying all human languages, their surface manifestations are so different in each language that translation may be an extremely difficult task to pursue. Hence, coping with the reality of untranslatability from one language to another (Schulte and Biguenet, 1992) has long been an inherently insurmountable task of translators.

The strenuous claim of untranslatability has been based on the apparent difficulties in finding linguistic equivalents from target language because of syntactic and semantic disparity between the source and target languages. However, it has been proved that much more than linguistic features are involved in the act of translation. Nida (1964) explained that the translatability of a text is assured by the existence of universal syntactic categories and further endorsed by the logic of experience. Furthermore, deconstructionism, as a new current of thought, claimed that through translation, language itself acquires a new identity of its own in a new culture, not solely as a form of representing meaning (Gentzler 1993). With these new and provocative changes in the nature of translation, the focus of translation scholars has begun to move from "text" to "culture." (Bassnett and Lefevere 1990).

\section{Translation and Cultures}

In a traditional quest of translation activities, translators try to understand the text and make others understand. However, several variables, especially intrinsic cultural inclinations are involved in the course of this seemingly linear practice. Recently, efforts have been continuously rendered to comprehend the inherent cultural perspectives in translation processes. Scholars including Bassnett (1992) defined tradition as an inter-cultural communication act. In this view, every text was considered to be embedded within a specific cultural setting, signifying that texts are established by using a set of culturally dependent and specific symbols. According to this perspective, the extent a text is translatable varies in accordance with how much the text is situated in its own specific cultures. Moreover, communications between remotely different cultures always pose practical difficulties for the translator due to differences in value systems, conceptual presuppositions, and historical antecedents (Nida 1993).

Based on this culture-oriented nature of translation as an interlingual and intercultural communicative process, pragmatic translation theory has been evolved subsequently. This theory situates the act of translating within a communicative frame, emphasizing more cultural influence in translation processes. In this theoretical framework, the concept of language in use and the language as a form of social action (Halliday 1985) reside at the core. Translators try not only to communicate specific textual meanings, but also to interpret what is fused in a specific culture at a specific time and place.

With a similar theoretical tenet, it has been argued that translation is a process which attempts to establish equivalents between two texts expressed in two different 
languages. These equivalents are, by definition, always dependent on the nature of the two texts, on their objectives, on the relationship between the two cultures involved (Cary 1985). This theoretical posture evidently illustrates the importance of understanding cultures in translation ventures.

\subsection{Linguistic and Cultural Equivalents}

The idea of translation equivalents, especially in the interpretive translation model, implies that finding an adequate equivalent is a goal a translator should pursue (Hatim and Mason 1990). If translators fail to recognize any specific meanings reflected in particular cultural milieux, they will probably fail to complete the tasks. Theoretically, there are almost no exact semantic synonyms between any two languages, but it is possible to build interlingual equivalences or correspondences between specific items in specific contexts (Nida and Reyburn 1981).

According to the interpretive theory of translation, a translator should transfer the intrinsic intentions of the authors of the original texts to the readers (Lederer 2003). This transferring presupposes understanding of the various variables in the text and reconstructing them in the target language. Cultural presuppositions and diverse conditions have been proved to immensely influence the nature of these inwardly fused but noteworthy factors. In this context, translation is the combination of a conscious effort to comprehend meanings and intuitive implications expressed in the text, which is impossible without a through understanding of cultural ramifications diffused in the text and the comprehension of the relationship between languages and cultures.

\subsection{The Relationship between Languages and Cultures}

Language mirrors various aspects of cultures, supports them, and spreads them. While language is clearly a product of cultures, this special feature of language distinguishes it from all other aspects of cultures and makes it crucially important for the transfer of cultural values. One of the most important cultural products is a language and Kramsch (1998: 3-4) succinctly describes the interrelatedness between language and culture in three points: language expresses cultural reality, language embodies cultural reality and language symbolizes cultural reality.

In conjunction with this essential and intimate relationship between language and culture, if people from two radically different cultures do not understand each other, it is not because their languages cannot be mutually translated. It is because they do not agree on the meaning and the value of the concepts covering the words. Conversely, they do not understand the reality of categorized experience in the same manner. This indicates that understanding across languages does not so much rely on structural equivalences but on common conceptual systems, formulated by the larger context of the cultural experience (Kramsch 1998).

With this social nature of language and cultures, Bruner (1986: 131) said, "Language serves the double function of being both a mode of communication and a medium for representing the world about which it is communicating." Within this realm, it is impossible to ignore the impact of value and conceptual systems taught and handed down by cultures. According to Vygotsky (1986), who had delved into 
the intricate relationship between language and thought, language was an agent for altering the powers of thought by giving a thought new means for explicating the world.

Furthermore, it has been constantly demonstrated that aesthetic differences as important aspects of cultural reality, affect the process of translation. A translator, as an individual belonging to a specific culture, is bound to be influenced by the aesthetic traditions in the particular culture. According to Kroeber and Kluckhohn (1963: 357), culture systems are "conditioning elements of further action." Consequently, every cognitive action and decision presupposes cultural understanding and considerations beforehand. As Brooks (1975: 30) states, "culture links the thoughts and acts of an individual to the common patterns acceptable to the group." These views on the influence of culture are further elaborated in Fleck's theory of the thought collective. According to Fleck (1979: 39), a thought collective is "a community of persons mutually exchanging ideas or maintaining intellectual interaction, the members of which share in, contribute to, and draw upon the collective for their experiences and ideas."

Emphasizing the influence of culture on thought mechanisms, Sapir-Whorf formulated a hypothesis stating that different linguistic communities have different ways of experiencing, categorizing, and organizing reality (Gorlée 1994). Sapir (1956) claims that no two languages are ever sufficiently similar to be considered as symbolizing the same social reality. The worlds in which different societies live are distinct worlds, not merely the same worlds with different labels. The strong version of Whorf's hypothesis, that language determines the way we think, is no longer considered valid. However, a weak version, that there are cultural differences in the meanings evoked by common concepts, is generally accepted these days (Bassnett 1993).

\subsection{Cultural Schemata}

Another influential and important concept related to the cultural effect on human cognitive activity is cultural schemata (Pritchard 1990). In the schemata theory, a person's perceptions and judgments are believed to be affected and determined by the assumptions shared by the groups to which the person belongs. This process of selecting and deciding sensory input subsequently results in the creation and instantiation of schemata, which are available for use with new information encountered. For example, it was observed that the political culture (Hulpke 1991) of a specific society always exercises certain constraints on the process of translating. Therefore, in a politically sensitive society, the translator generally makes a conscious effort to avoid any interference with the established political norms.

According to a study on the impact of schemata on reading processing, it was found that cultural schemata influence readers' processing strategies and the level of comprehension they attain (Pritchard 1990). Translators always use their background knowledge, the situational contexts and the cues provided by an author of the ST to construct an interpretation of the meaning of a text. Therefore, a passage dealing with a culturally familiar topic will be easier to comprehend, assuming all other factors are the same, than a culturally unfamiliar one. This is possible because the schemata embodying translators' background knowledge about the content of culturally familiar materials facilitate the integration of understandings and enable translators to achieve a unified meaning of the text. The translators can and must be able to activate 
and utilize the relevant schemata connected with any particular text in order to expedite comprehension of the culturally familiar text. To support this claim, many studies have demonstrated that comprehension of a culturally unfamiliar text is more difficult than comprehension of a culturally familiar text (Johnson 1981; Lipson 1983). Frequently in translation, what really counts is not language, but culture, because the meaning intended by the author can only be determined with reference to the cultural contexts.

As a further indication of how cultural values influence the thought systems of people living in the cultures, one cross-cultural study (Pae 1998) demonstrates a distinct difference in value systems between Korea and USA as shown below.

TABLE 1

The difference in value system between Koreans and Americans

\begin{tabular}{|l|l|}
\hline Korean & American \\
\hline Confucian undercurrent & Judeo-Christian Substratum \\
\hline Abstract way of thinking & Scientific way of thinking \\
\hline Status-conscious & Egalitarian \\
\hline Conformist & Individualistic \\
\hline Formalistic & Pragmatic \\
\hline Emotional & Rational \\
\hline Suggestive & Direct \\
\hline
\end{tabular}

Even though there is a risk of overgeneralization in this dichotomous differentiation between Korean and American value systems, this information can be a reference upon which cross-cultural study on different styles of translation can be formulated. In fact, cultures invariably and incessantly invite comparison and juxtaposition; they are not only the places where meanings are made, but the space in which they are being exchanged, transmitted and seek to be translated from one language into another. As an extreme example, even abandoning native speech does not cancel the culture to which it belongs, but merely defines its meanings on a new scale offered by the "foreign" language (Toporov 1992). It is subject to further analysis whether cultural ramifications remain intact while their applications and metamorphosis in another language through the translation process.

\subsection{Mediation in Translation}

Translators often resort to different levels of strategies of which definition can be termed as "a potentially conscious procedure for the solution of a problem, in which an individual is faced with when translating difficult texts (Hatim 2001).” Additionally, in an effort to minimize any possible misunderstanding caused by the difference in cultures between ST and TT, competent translators make relevant mediations in adjusting their translations with the target culture standards. As clearly illustrated in Cheong (2004), translators use mediation devices including explication/implication and expansion/contraction of the translated texts to maintain relevance throughout the text and convey intended meanings from ST to TT.

In this study, the Vygotskian theoretical framework of the mediation was employed as a vehicle to understand the strategic collaboration between two translators whose 
cultural backgrounds are vastly different. Vygotsky (1978) has elaborately demonstrated that higher mental functioning of human beings is mediated by tools and signs. One of the most important components of these tools is a language. The fundamental claim in Vygotsky's notion of mediation is that any type of human activities can be mediated through these mental activities. These kinds of cognitive ventures, which are evidently within the realm of the sociocultural activities, are not so much simply facilitating activities but fundamentally shaping and defining works. This idea dictates that during the concept development processes between two people, there can be an essential shift in cultural perspectives. This shift was enabled by the path of mediation, from intrapsychological level to interpsychological plane (Wertsch 1990). Cultural concepts or solution strategies exclusively inherent in one participant can be transferred to another participant and duly internalized by the recipient creatively during the process. This is a particularly effective and powerful tool for finding solutions through conscious awareness raising and reciprocal efforts between participants (Moll 1990).

\section{Methods}

\subsection{Research Designs}

This case study was designed to examine how the difference in cultural schemata interacts and influences comprehension of the translated material and what strategies the translators employ to cope with ambiguities encountered during collaborative translation processes. Two translators from Korea and USA participated in collaborative translation of the text from Korean to English. The title of the translated material is "The Japanese perception of Tokdo (the name of an island) during the opening of ports." This is an article about a very controversial and sensitive issue as Tokdo has become a center of territorial conflict between Korea and Japan. Tokdo is the easternmost territory of Korea and Japan has claimed its territorial right on this island for several decades. Originally this article was translated as a part of a project prepared for a special edition on the issue of Tokdo for a Korean government-sponsored English academic journal. In an effort to ensure its translation quality and objectivity for readers whose comprehension language is English, the translation was designed to be conducted in a collaborative mode. The translation proceeds in the following pattern. First, the Korean translator put the Korean article into English and then a well-educated native speaker of English (American, a doctoral student in language education) worked on the article to point out any parts that needed to be corrected or improved to make the article appropriate for educated readers in the USA. Initially it was anticipated that this collaborative working mode would be beneficial through a synergetic mode of cooperation and as the recordings of interactions piled up, several interesting situations were observed.

In order to accurately record every interaction between the translators during this transaction, exchanges of ideas and comments took place through e-mail. The Korean translator first sent his version of translation to the American translator. The American translator corrected and sent the text back to the Korean translator with questions and comments in order to clarify the ambiguity and improve the understanding for readers. Gathered data demonstrated a series of mediation endeavors between two translators before they reached agreement on satisfied final translation idea. 
Van Dijik and Kintsch (1983: 64-65) defined strategy in cognitive activities as "the idea of an agent about the best way to act in order to reach a goal." Moreover, Brown (1980: 456) describes a strategy as "any deliberate, planful control of activities." In this study strategy is defined as purposeful and collaborative actions taken voluntarily to achieve smooth and effective translation over culturally-embedded and ambiguous texts.

\subsection{Data Collection and Analysis}

Previous studies on strategic collaboration (Tharp and Gallimore: 1991) and mediation processes (Vygotsky 1987) provided a theoretical framework for the following analytical taxonomy as a basis for full-fledged and dialectical analysis of every interaction. Additionally, Pritchard (1990) proposed the sequence of cognitive activities in reading processes to explain how the cultural schemata influence the overall reading comprehension processes and the principles of establishing this taxonomy were applied to this study.

1) Taxonomy of processing strategies in collaborative translation

A. Developing cultural awareness and facilitating textual comprehension

1. Understanding the text by activating cultural knowledge

2. Analyzing texts and finding equivalents

B. Negotiating on ambiguities and dealing with differences

1. Conflicts on difference in lexicon and structures

2. Coping with ambiguities and differences

C. Perspective shifting through mediation

1. Mediation processes

2. Approach to mediated products

\section{2) Data Analysis}

Data for analysis consist of e-mail transactions accumulated for a period of one month. Every exchange of ideas and opinions on translation materials was collected and analyzed in accordance with taxonomy of processing strategies as formulated above and data that did not fall into categories under the above taxonomy were discarded from analysis. The joint endeavors in each component did not necessarily occur sequentially with the lapse of time, but rather in a parallel mode during translation collaborations. If questions arise regarding ambiguities in meaning or cultural implications that need clarification, both translators exchange opinions on any issues and discuss optimal solutions for smooth and successful processing of the translation. Sentences with bold print indicate either correction of the translation or exchanges of opinions on the translation.

(A) Developing cultural awareness and facilitating textual comprehension

1. Understanding the text by activating cultural knowledge

2. Analyzing texts and finding equivalents

The Korean translator tried to translate the original words and intentions expressed in ST and there were some exchanges of opinion to clarify the exact meanings in different political and cultural settings. The two translators tried together to find out the closest equivalents of the words and concepts expressed in ST. 
(Case 1) Korean Translator (KT): Yomiuri Shinbun published an editorial on February $21^{\text {st }}$ which maintained that the Tokdo island belongs Japan in light of historical and legal grounds.

American Translator (AT): Yomiuri Shinbun [Is this a newspaper? Use "published" but if this is a person, use "wrote"] an editorial on the twenty-first of February maintaining that the Tokdo island belongs to Japan in light of historical and legal grounds

Here the Korean translator thought that the word "published" was sufficient to indicate that Yomiuri Shibun is a newspaper (Japanese), the American translator wanted clarification on the use of this word.

(case 2) KT: Naturally these activities caused the anger of Korean news media and intelligentsia, thus Korea-Japanese relations are being deteriorated.

AT: Such activities naturally angered members of the Korean news media and intelligentsia, causing a deterioration in Korean-Japanese relations.

(case 3) KT: Nonetheless, Japan argued that the notice made by Sinema Hyun is just appropriate in terms of international law and satisfy the first occupation theory.

AT: Nonetheless, Japan has argued that the notice [Is this an official claim document like a proclamation?] made by Sinema Hyun is sufficient in terms of international law to satisfy the requirements of first occupation theory [Is this the real name of the theory?]

(case 4) KT: Moreover, they tried various measures in an effort to...

AT: In addition, they [referent unclear again] attempted to...

(case 5) KT: It is well known that they proclaimed "respect the king and repel the foreign influence" slogan..

AT: The federal lords [All of these "theys" without explanations are confusing - that must be the influence of dropping the subject in Korea. Maybe you should try to specify as much as possible, especially since many English readers may not have complete background knowledge.] are known to have proclaimed a "respect the king and repel the foreign influence" slogan...

The Korean translator made the translation in order to convey intentions and meanings expressed in the ST and the American translator, with an analytical perspective on cultural settings for US readers, tried to be as objective and specific as possible by avoiding any ambiguities. For example, the American translator thought that the use of words including notice and theory should be supported by the relevant contexts and background explanation for logical linearity.

(case 6)

KT: The Makbu was dissolved in 1868

AT: The Makbu government was dissolved in 1868

(case 7)

KT: Kido repeatedly argued that the standing army should be ready.

AT: Kido repeatedly argued that the standing army should be battle ready.

Here again, the American translator showed a tendency to be unbiased and accurate while the Korean translator thought his translation was sufficient to convey the intentions expressed in the ST. This difference could be a source of conflict between the translators, but collaboration continued and mediation efforts were rendered through negotiation as shown in the following examples. 
(B) Negotiating on ambiguity and dealing with differences

1. Conflicts on difference in lexicon and structures

2. Coping with ambiguities and differences

The two translators showed intermittent conflicts on the choice of relevant equivalents and how to cope with ambiguities in ST in order that the US readers would comprehend the text smoothly while keeping the original intentions and emotions expressed in the original text intact.

(case 1) KT: Among them, noteworthy are Shin Yongha's "Possession of Tokdo by Chosun Dynasty and invasion of the Japanese empire to Tokdo," and Yang Taejin's "The study of Korean borders."

AT: Noteworthy are Shin Yongha's [perhaps include date] "Possession of Tokdo by Chosun Dynasty and invasion of Japanese Empire to Tokdo," [This is awkward, but I don't know if it is okay to change a title you are citing. If the study has not been translated into English, I sure would suggest alternate title like: "Tokdo: Possession by the Chosun Dynasty and Invasion by the Japanese Empire" or The Possession of Tokdo by the Chosun Dynasty and its invasion by the Japanese Empire."]

(case 2) KT: ...the idea of occupying Chosun at the end of the Makbu period surfaced..

AT: [What does this really mean? That someone wanted to occupy Chosun when the Makbu period finally came to an end or the idea of occupying Chosun became strong at the end of Makbu period?]

KT: [I think I should rearrange the sentence structure.]

(case 3) KT: It was considered that an intention of the letter was to provoke Chosun to refuse acceptance of the letter and ...

AT: It was considered [by who? Chosun? Japanese officials? Current scholars?] that the letter was intended to provoke Chosun into refusing to...

KT: [It should be Chosun.]

(case 4) KT: Japan has assiduously gathered and emphasized every document which can negate the fact that Chosun had already known the existence of Tokdo.

AT: Japan has assiduously gathered historical documents relating to its claim, emphasiz-

ing those which cast doubt on Chosun's knowledge of Tokdo's existence.

The translators attempted to cope with the differences and came to mutually acceptable agreement on the choice of equivalents through collaboration as shown below.

(case 5) KT: There are the six logical arguments upon which Japan has relied.

AT: [I'm not happy with “frameworks' as a plural, but if you want to keep the idea of framework, I suggest: These six arguments from the logical framework upon which Japan's assertion of dominion over Tokdo rely.]

KT: [OK I agree with you]

(C) Perspective shifting through mediation

1. Mediation processes

2. Approach to mediated products

The two translators went through mediation with a strategic goal of completing the translation for relevant readers whose comprehension language is English. 
Through dialogue during the mediation processes, the final translation products began to be materialized as displayed below.

(case 1) KT: San Francisco convention after World War 2 made a list of islands that should be returned and Tokdo was not included.

AT: Delegates to [or "participants in"] the San Francisco convention [need an official name here], following World War II created [conventions don't create or make anything their attendees do] a list of islands to be returned [to where? Korea?] and this list did not include Tokdo [alternative:... a list of islands to be returned which did not include Tokdo].

KT: [I know what you mean. It is not clear who attended the SF convention and officials' name were not available, either. I think I'll add participants as you suggested. Also, "a list of islands to be returned.." is better]

(case 2) KT: ...even though there is evidence the Japanese Makboo and Meiji regime have obviously recognized that Tokdo belongs to economic zone of Ulungdo.

AT: [I assume that the writer has some evidence since s/he states "obviously" in the next line, but it sure would be nice if the evidence is included in this discussion. I am not convinced any more by unsupported claims to Tokdo by Koreans than I am impressed favorably by Japan's assertions. It's too bad we're not editing the Korean first for content and then translating it for language.]

KT: [I agree with you, but we have to make a final product anyway. The use of evidence is not relevant considering the apparent lack of actual evidence here. But I think we have to come up with something to satisfy the original claims of the text and find out equivalents. That's what translators do. We are not supposed to make comments.]

(case 3) KT: In the meantime it seems that Japan revived tactics to compel concessions from oriental countries.

AT: ["In the meantime" makes no sense to me here because there has not been a parallel activity. It actually means "at the same time" or "meanwhile." Usually the time is the same, but the location or type of activity is different - I don't get a sense of that use here.] Japan appears to have resumed their former tactics, attempting to compel concessions from Asian [ $I$ think "orient' is used in reference to art and design these days.] countries.

KT: [OK. I will change oriental to Asian. I forgot that oriental in your culture has a little negative connotation.]

(case 4) KT: As verified in Lee Hoon's article, the territorial clash over Ulungdo was completely settled ...

AT: As shown [how was this a verification of the facts? Was a photocopy of the relevant record included? Too strong a word otherwise.] in Lee Hoon's article [cite], the territorial clash over Ulungdo was completely settled...

KT: [The author of this article wanted to use a strong word like "verify" to show his emotion on the issue of Tokdo. But, I think you are right that US readers would find the use of this word somewhat odd due to the lack of evidence to support this claim.]

(case 5)

KT: ...but it shows the misrepresented historical perception of Japan and this became a historical framework for Japanese government of the time and can be seen as providing a historical framework for colonial historical view.

AT: It illustrates the historical perceptions of the Japanese government ...

KT: [To mirror the nature of this article fully, I think the word of misrepresented should be added.]

AT: [ You are supposed to make a final decision on this.] 


\subsection{Discussion}

As was revealed earlier (Pae 1998), it is a general belief that American way of thinking is logical and linear whereas it is not the case of Korean way of thinking and making decisions. Moreover, cultural differences exercise a significant influence on the way of thinking (Kramsch 1988). However, the above observation in the analysis of reciprocal transactions between the translators from two radically different cultures aptly demonstrated that two participants have actively engaged in pursuing strategic problem-solving mediation to achieve a goal over the difference in their cultures. Vygotsky claimed that human development is relational. It consists of internal consciousness as well as external behaviors, cognitive processes as well as social ones. According to Vygotsky (1979:1),

The mechanism of social behavior and the mechanism of consciousness are the same $[\ldots]$ we are aware of ourselves, for we are aware of others, and in the same way we know others; and this is as it is because in relation to ourselves we are in the same [position] as others to us.

The tools used in this collaborative process are interpersonal dialogue or active exchanges of opinions. As Kozulin (1993) pointed out, Vygotsky's approach “required that the typology of the semiotic means of mediation should be complemented by the topology of the overt and inner dialogue in which culture acquires its psychologically individual form (p. 36-37).” These interactions include highly logical and abstract dialogue as well as "spontaneous dialogue." In strategic collaboration between two people with a task at hand, constant dialogues are required to explore the nature of the problems (task) they are faced with. Gradually, they come to a common ground of mutual understanding and further actions to be taken. This relationship is similar to the one performed during the "scaffolding" process as termed by Wood, Bruner and Ross (1976). These dialectical processes during collaboration efforts in this paper can be summarized as in the following figure.

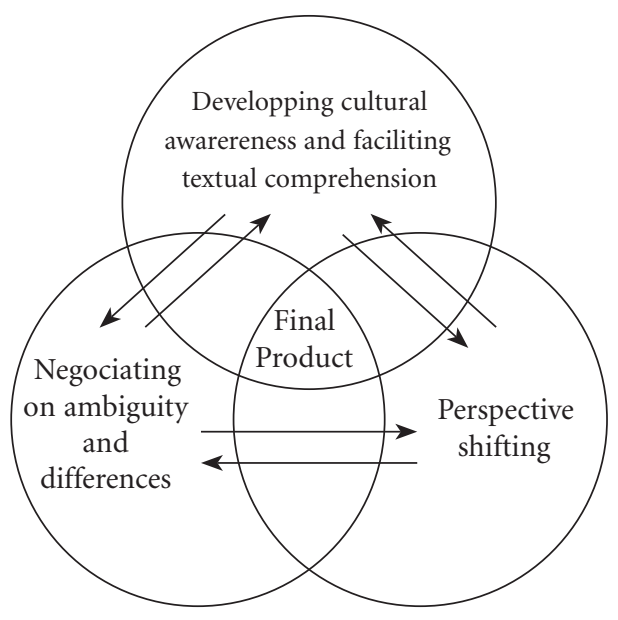




\section{Conclusion}

The traditional view on translation dictates that differences in cultural understanding and strategies together with attitudes toward cultural difference may cause differences in translation products. With this tenet, it is very difficult to elucidate overall intrinsic processes during translation endeavors. Even if a translating process can be dissected into several controllable steps, it would be extremely difficult to find linear or automatized translation procedures directly related to finding final solutions. As Lörscher (1996) refers to translation as a "chain of spirals or loops," this paper showed that the translation consists of constant applications of mediation and solutionsearching techniques. This article is an attempt to explain the notion of mediation processes gleaned from collaborated efforts of translating culturally ambiguous texts. Data analysis in a case study reveals that dialectical and reciprocal translation processes were created between Korean and American translators. Analytical criteria to determine various collaboration types were established based on the previous studies and review of exchanges during collaborations. The analysis of actual opinions and comments rendered between two translators suggests an alternative translation method for culturally ambiguous texts by applying strategically mediated procedures. Further studies with more cases with other combinations of languages are expected to reveal more details on transitional procedures and products obtained through this type of translation endeavor.

\section{REFERENCES}

Bassnett, S. (1992): Translation Studies, London and New York, Methuen.

BAssnett, S. (1993): Comparative Literature. A Critical Introduction, Oxford, UK and Cambridge USA, Blackwell.

Bassnett, S. and A. Lefevere (1990): Translation, History and Culture, London and New York, Routledge

Brooks, N. (1975): “The Analysis of Language and Familiar Cultures,” In R. C. Lafayette (Ed.), The Cultural Revolution in Foreign Language Teaching, Skokie, IL, National Textbook Company.

Brown, A. L. (1980): “Metacognitive Development and Reading," In R. J. Spiro, B. C. Bruce and W. F. Brewer (Eds.), Theoretical Issues in Reading Comprehension, Hillsdale, NJ, Erlbaum.

Bruner, J. S. (1986): Actual Minds, Possible Worlds, Cambridge and London, Harvard University Press.

CARY, E. (1985): Comment faut-il-traduire, Press Universitaires de Lille.

Cheong, H. J. (2004): "Translated Text Expansion and Contraction Phenomenon: A Corpus-Based Study of Quantitative Target Text Changes as Reflective of Translation Mediation," unpublished doctoral dissertation, Hankuk University of Foreign Studies.

FleCK, L. (1979): Genesis and Development of a Scientific Fact, Chicago, University of Chicago Press.

Gentzler, E. (1993): Contemporary Translation Theories, London and New York, Routledge. Gorlée, D. L. (1994): Semiotics and the Problem of Translation, Amsterdam, Editions Rodopi. Hatim, B. (2001): Teaching and Researching Translation, Harlow and New York, Longman. Hatim, B. and I. Mason (1990): Discourse and the Translator, London and New York, Longman. Halliday, M. A. K. (1985): An Introduction to Functional Grammar, London, Edward Arnold. Hulpke, E. (1991): "Cultural Constraints: A Case of Political Censorship," In Kittel and Frank (Eds.), Interculturality and the Historical Study of Literary Translations, Berlin, Erich Schimidt. Johnson, P. (1981): "Effects on Reading Comprehension of Language Complexity and Cultural Background of a Text,” TESOL Quarterly 15, p. 169-181. 
Kozulin, A. (1993): "Vygotsky in the Context," In A. Kozulin (Ed. and translated), Thought and Language, Cambridge, MA, MIT Press.

Kramsch, C. (1998): Language and Culture, London, UK, Oxford University Press.

Krober, A. L. and C. Kluckhonn (1963): Culture: A Critical Review of Concepts and Definitions, New York, Vintage.

Lederer, M. (2003): Translation: The Interpretive Model (translated by N. Larché), Manchester, UK, St. Jerome Publishing.

Lipson, M. Y. (1983): The Influence of Religious Affiliation on Children's Memory for Text Information, Reading Research Quarterly 18, p. 448-457.

Lörscher, W. (1996): A Psycholinguistic Analysis of Translation Process, Meta 41-1, p. 26-32.

Moll, L. C. (ed.) (1990): Vygotsky and Education: Instructional Implications and Applications of Sociohistorical Psychology, London UK, Cambridge University Press.

Newmark, P. (1998): More Paragraphs on Translation, Clevedon and Buffalo, Multilingual Matters.

NidA, E. A. (1964): Toward a Science of Translating, Leiden, E. J. Brill.

NidA, E. A. (1993): Language, Culture and Translating, Shanghai, Shanghai Foreign Language Education Press.

Nida, E. and W. Reyburn (1981): Meaning Across Cultures, American Society of Missiology Series 4, New York, Orbis Books.

NidA, E. and C. TABer (1969): The Theory and Practice of Translation, Leiden, E. J. Brill.

PAE, Y. J. (1998): "Cross-cultural Clash between Korean and American People," Journal of the Applied Linguistics Association of Korea 4-2, p. 59-94.

Pitchard, R. (1990): "The Effects of Cultural Schemata on Reading Processing Strategies," Reading Research Quarterly 24, p. 273-295.

SAPIR, E. (1956): Culture, Language and Personality, Berkeley and LA, University of California Press.

Schulte, R. and J. Biguenet (1992): Theories of Translation: An Anthology of Essays from Dryden and Derrida, Chicago and London, University of Chicago Press.

Tharp, R. G. and R. Gallimore (1991): Rousing Minds to Life, NY, Cambridge University Press.

Toporov, V. N. (1992): “Translation: Sub specie of Culture," Meta 37-1, p. 29-49.

Van Dijik, T. A. and W. Kintsch (1983): Strategies of Discourse Comprehension, New York, Academic Press.

Vygotsky, L. S. (1978): Mind in Society: The Development of Higher Psychological Processes, MA, Harvard University Press.

Vygotsky, L. S. (1979): “Consciousness as a Problem of Psychology of Behavior," Soviet Psychology, p. $1729-1730$.

Vygotsky, L. S. (1986): Thought and Language, Cambridge, MA, MIT Press.

Vygotsky, L. S. (1987): Collected Works of L. S. Vygotsky: Vol. 1: Problems of General Psychology (translated by

N. Minick; Series editors R. W. Rieber and A. S. Carton), New York, Plenum Press.

Wertsch, J. V. (1990): “The Voice of Rationality in a Sociocultural Approach to Mind," In L. MolL (Ed.), Vygotsky and Education, Cambridge, MA, Cambridge University Press.

Wilss, W. (1982): The Science of Translation. Problems and Methods, Tübingen, Gunter Narr Verlag.

Wood, D. J., Bruner, J. S. and G. Ross (1976): “The Role of Tutoring in Problem Solving,” Journal of Child Psychology and Psychiatry 17-2, p. 89-100. 